\title{
9
}

\section{Upflow Filtration for the Treatment of Stormwater at Critical Source Areas}

\author{
Uday Khambhammettu, Robert Pitt, Robert Andoh, and \\ Shirley Clark
}

One approach to the treatment of urban runoff is to treat the runoff from critical source areas before it mixes with runoff from less pollutant areas. Some of the general features of critical source areas appear to be large paved areas, heavy vehicular traffic, and/or exposed heavy equipment, materials or products. The control of runoff from relatively small critical source areas (such as loading docks, fueling areas, small maintenance yards, etc.) may be the most cost effective approach for the treatment/reduction of stormwater toxicants. However, in order for a treatment device to be usable, it must be inexpensive, both to purchase and to maintain, and be effective.

Upflow filtration of stormwater was tested during both controlled tests, and under actual rainfall conditions, during SBIR1 (Small Business Innovative Research) and SBIR2 research funded by the US EPA. This chapter summarizes the work presented by Pitt, et al. (2005), Khambhammettu (2006), and Pitt, et al. (2006) reporting on this research. Upflow filtration was originally developed to overcome some of the problems associated with conventional filtration. The most serious problem is that downflow filters clog relatively quickly, reducing the treatment flow

Khambhammettu, U., R.E. Pitt, R. Andoh and S. Clark. 2007. "Upflow Filtration for the Treatment of Stormwater at Critical Source Areas." Journal of Water Management Modeling R227-09. doi: 10.14796/JWMM.R227-09.

(C) CHI 2007 www.chijournal.org ISSN: 2292-6062 (Formerly in Contemporary Modeling of Urban Water Systems. ISBN: 0-9736716-3-7) 
rate potential and total treatment capacity, potentially causing large amounts of the stormwater to bypass the treatment units. Clogging does not occur as fast with upflow filtration. One reason is that the heavier particles are drawn away from the filtration interface due to gravity and fall into the sump which is an integral part of the upflow filter design. Figures 9.1 and 9.2 are schematics of the prototype $\mathrm{UpFlo}^{\mathrm{TM}}$ filter that was evaluated at Tuscaloosa, $\mathrm{AL}$, as part of the SBIR2 tests. Figure 9.3 is a drawing of the full-scale commercial $\mathrm{UpFlo}^{\mathrm{TM}}$ filter that is undergoing EPA ETV (Environmental Technology Verification) testing at Penn State - Harrisburg.

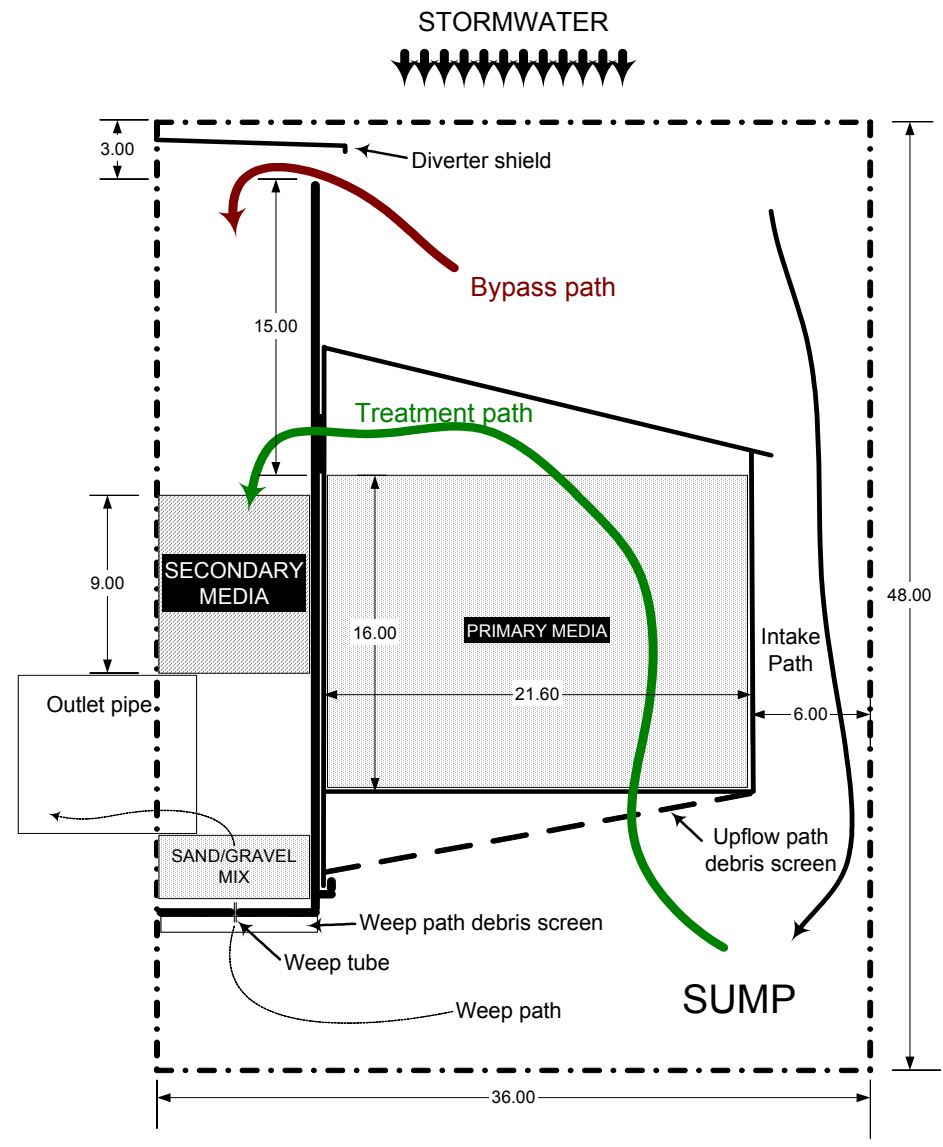

Figure 9.1 Side view of $\mathrm{UpFlo}^{\mathrm{TM}}$ filter. 


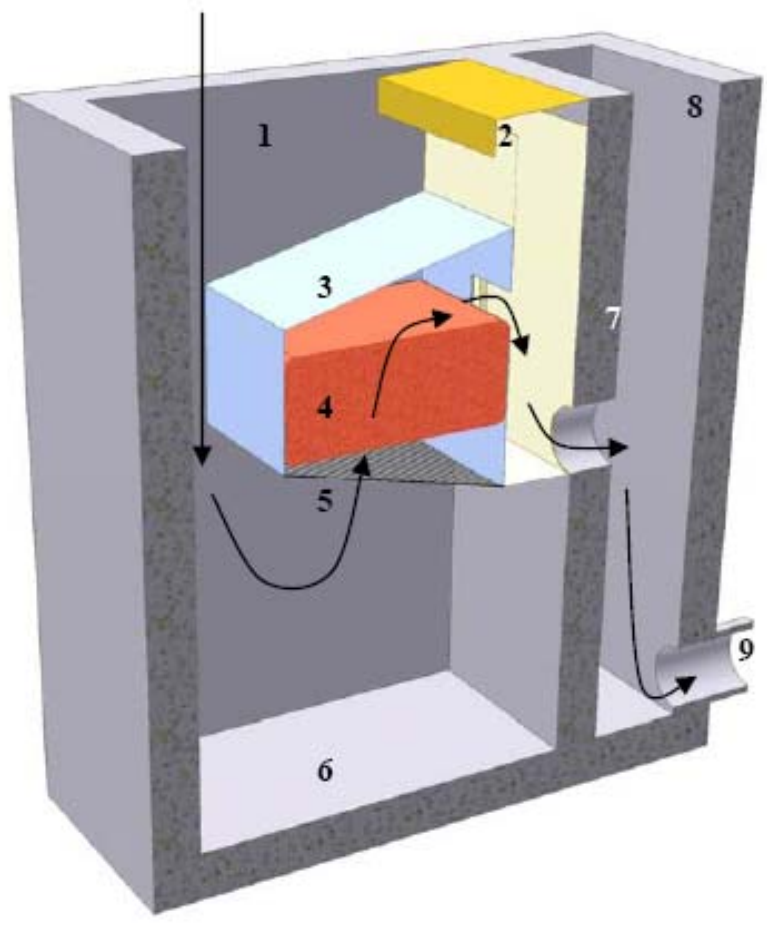

Figure 9.2 Schematic of Up-Flo ${ }^{\mathrm{TM}}$ Filter prototype (Hydro International, Ltd).

1. Filtration chamber

2. Bypass with floatables baffle

3. Media housing

4. Filtration media

5. Angled screen

6. Sump

7. Baffle wall

8. Effluent chamber

9. Outlet pipe

10. Weep tubes (not shown) 


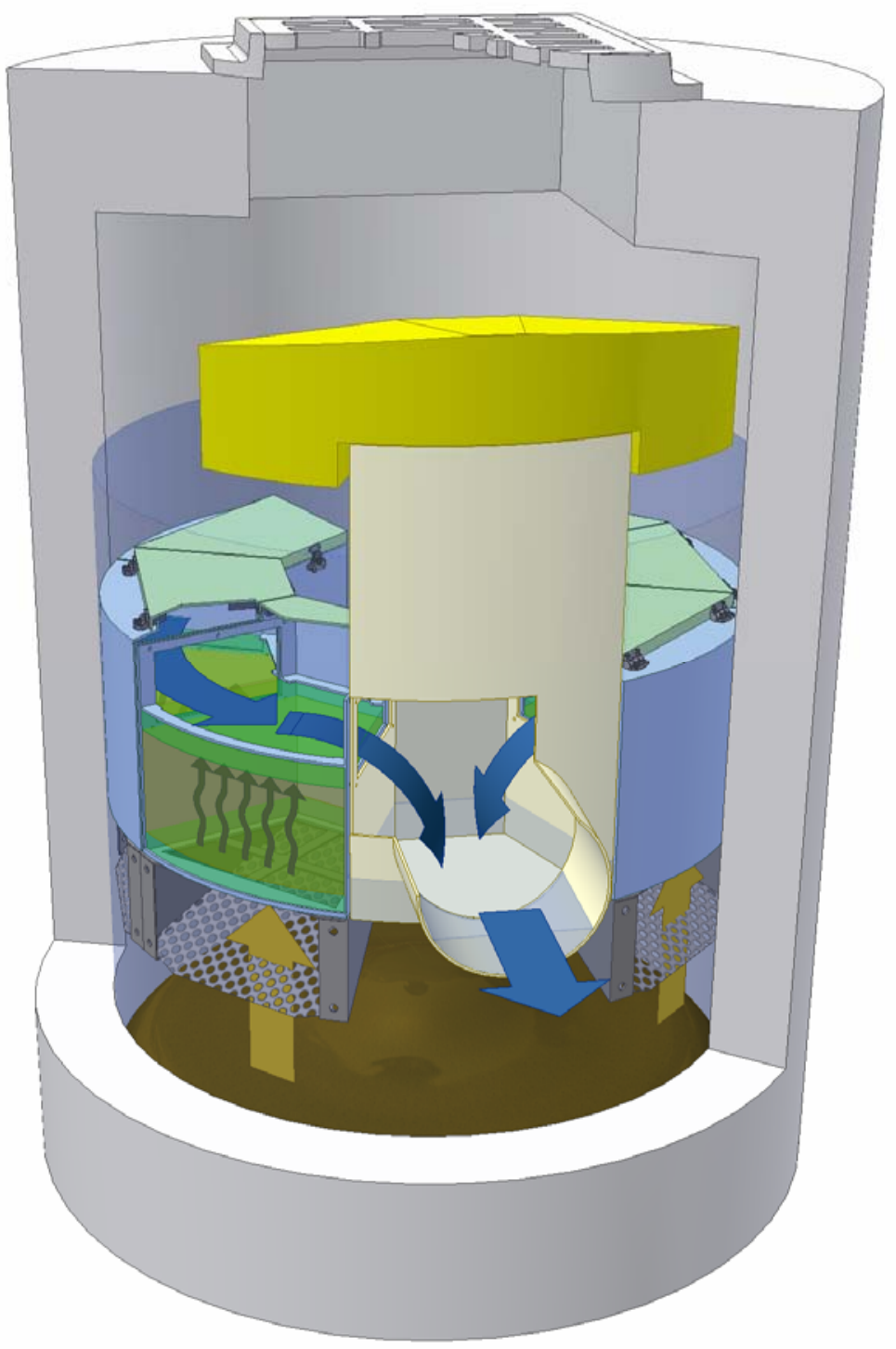

Figure 9.3 $\mathrm{UpFlo}^{\mathrm{TM}}$ filter drawing during normal filtering operation (Hydro International, Ltd.). 


\subsection{Introduction}

Numerous manufacturers have developed proprietary devices to treat stormwater runoff. These devices have been designed to treat one or more of the common stormwater pollutants - solids, metals, oil and grease, nutrients and bacteria. Few have been designed to treat a broad range of pollutants in a single device. In addition, many of these devices provide inconsistent performance from one installation to another. Treatment of runoff from critical source areas requires a device with robust removal ability.

The performance of the prototype Upflo ${ }^{\mathrm{TM}}$ filter has been tested under controlled flow and actual storm events with the following objectives

- to determine how the head loss and associated treatment rate change during upflow filtration;

- to evaluate the effect of decreasing/increasing the filter flow rate on the treatment efficiency; and

- to predict the performance of the upflow filtration for various pollutants.

\subsection{Controlled Flow Tests}

The maximum flow capacities for different media were determined using measured flows. The controlled particle trapping tests were then conducted at high, medium and low flow rates (full flow, $1 / 2$, and $1 / 4$ of the maximum flow rates) with varied influent sediment concentrations $(500 \mathrm{mg} / \mathrm{L}$, $250 \mathrm{mg} / \mathrm{L}, 100 \mathrm{mg} / \mathrm{L}$ and $50 \mathrm{mg} / \mathrm{L}$ ). Flow tests were conducted in the field with the cooperation of the Tuscaloosa Water Department by using a fire hose connected to a fire hydrant adjacent to the test site. The flows were measured using their calibrated meter, and also checked at the test rates by timing the filling of large containers. Maximum flow rates of about $30 \mathrm{gpm}$ $(1.89 \mathrm{~L} / \mathrm{s})$ were obtained during the tests, for a filter area of about $1.5 \mathrm{ft}^{2}$ $\left(0.14 \mathrm{~m}^{2}\right)$. Figure 9.4 shows how the flows varied for different hydraulic heads over the mixed media.

The sediment in the stormwater stimulant was based on the following mixture: Sil-Co-Sil 250, Sil-Co-Sil 106 (both from the U.S. Silica Co.), coarse sand, and fine sand. The mixture was made by using equal weight fractions of each of the four components. The test sediment particle size ranged from $0.45 \mu \mathrm{m}$ to $2,000 \mu \mathrm{m}$. More of the larger particles were 
included in the test mixture than expected in normal stormwater in order to be more confident of the expected very high removal rates for these large particles (the concentrations and removal rates were determined for eight separate particle size ranges, not just for the complete sample).

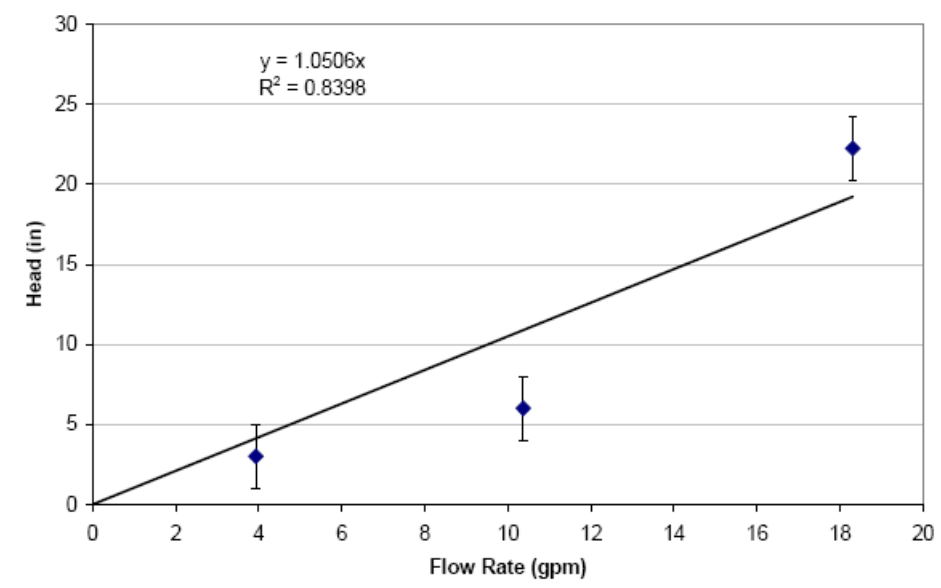

Figure 9.4 Flow characteristics for tested media.

A total of 21 separate controlled experiments were conducted, resulting in the collection of 84 samples, including the blank samples for each experiment. Total solids, suspended solids, total dissolved solids (by difference), and particle size distribution (PSD) analyses were carried out for each sample and its duplicate (duplicates were made from time composites in the field using a churn splitter). Therefore, the total number of samples analyzed during the controlled tests numbered 168. Before conducting the analyses, each of the 168 samples were split into 10 equal volumes of $100 \mathrm{~mL}$ each using a Decaport/USGS cone splitter for the separate analyses.

Figures 9.5 and 9.6 are example data plots for the controlled tests. Figure 9.5 shows the particle size distribution plots for the influent test mixture, and the measured effluent particle size distributions. Very few particles larger than $30 \mu \mathrm{m}$ were found in the effluent. Also, influent concentration and flow rate had little effect on the effluent particle size distributions. Beckmann Coulter Counter was used in analyzing the particle size distributions. 


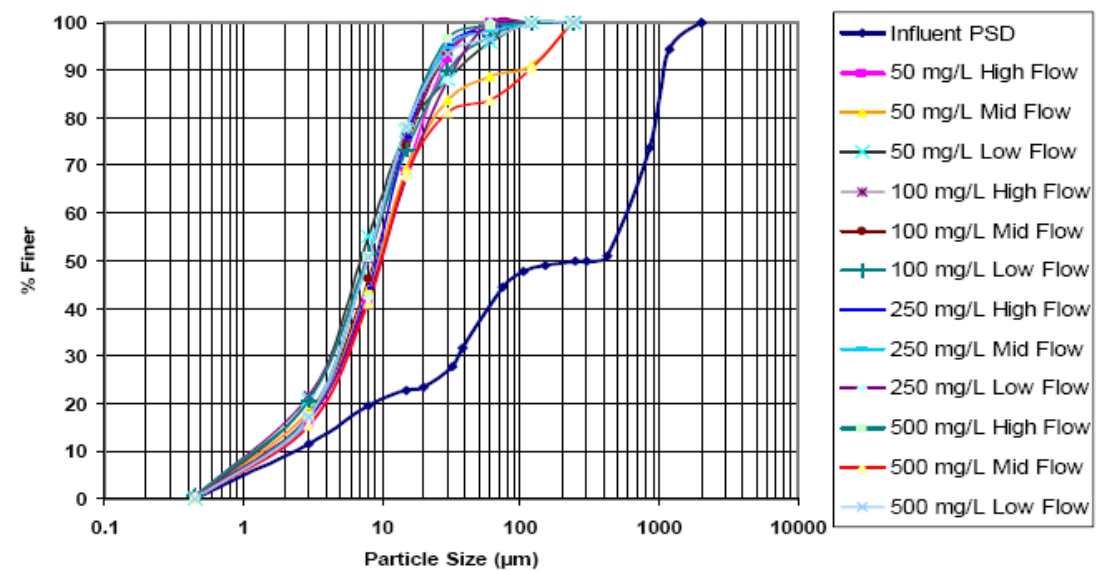

Figure 9.5 Performance plot of particle size distribution for mixed media.

Figure 9.6 indicates some very small improved levels of performance for lower flows at each concentration tested. The effluent concentrations were also about the same, but the lowest effluent concentrations were associated with the lowest concentration, lowest flow tests.

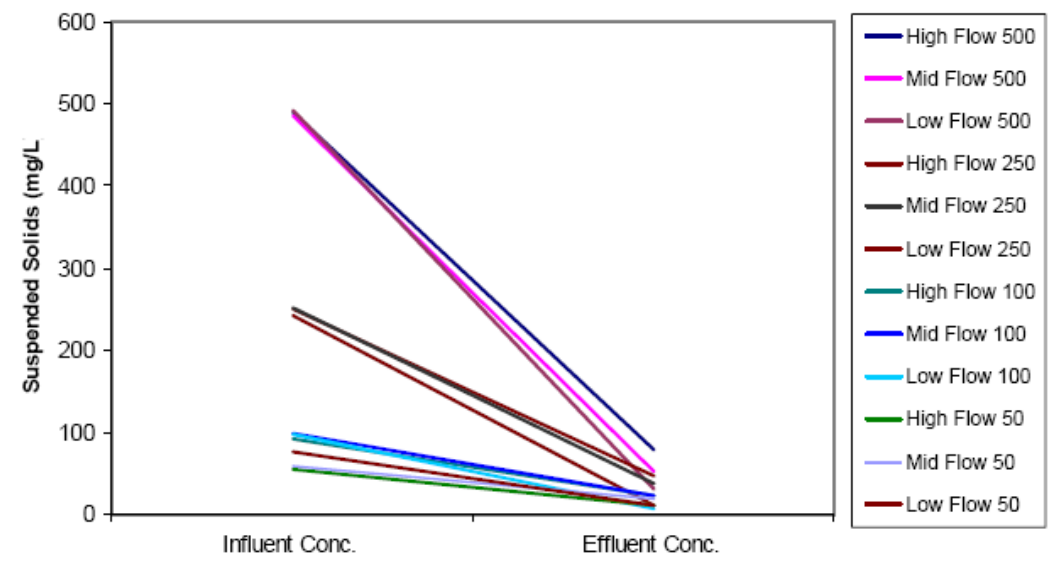

Figure 9.6 Performance plot for mixed media for suspended solids at influent concentrations of $500 \mathrm{mg} / \mathrm{L}, 250 \mathrm{mg} / \mathrm{L}, 100 \mathrm{mg} / \mathrm{L}$ and $50 \mathrm{mg} / \mathrm{L}$. 
Overall suspended solids removal efficiencies of 85 to $90 \%$ were observed for all of the controlled tests. As shown on Table 9.1, the larger particles were removed most effectively, as expected. The removals of the 0.45 to $30 \mu \mathrm{m}$ particles were about $50 \%$, while the removals of particles larger than $30 \mu \mathrm{m}$ were 95 to $100 \%$. The 0.45 to $30 \mu \mathrm{m}$ particle sizes indicated some irreducible concentration effects, below which no further removals were observed.

Table 9.1 High flow rate $\left(20 \mathrm{gpm} / \mathrm{ft}^{2}\right)$ controlled test results.

\begin{tabular}{ccc}
\hline Size Range $(\mu \mathrm{m})$ & $\begin{array}{c}\text { Effluent quality }(\mathrm{y}=\text { effluent concentration; } \mathrm{x}= \\
\text { influent concentration, both in } \mathrm{mg} / \mathrm{L} \text { of particulate } \\
\text { solids in designated size range) }\end{array}$ & $\begin{array}{c}\text { Approx. irreducible } \\
\text { concentration in size } \\
\text { range }(\mathrm{mg} / \mathrm{L})\end{array}$ \\
\hline 0.0 to 0.45 (TDS) & $\mathrm{y}=\mathrm{x}$ & na \\
0.45 to 3 & $\mathrm{y}=0.6057 \mathrm{x}+1.2409$ & 2.0 \\
3 to 12 & $\mathrm{y}=0.6371 \mathrm{x}+0.5216$ & 1.4 \\
12 to 30 & $\mathrm{y}=0.6279 \mathrm{x}+1.5312$ & 4.1 \\
30 to 60 & $\mathrm{y}=0.0414 \mathrm{x}$ & 0 \\
60 to 120 & $\mathrm{y}=0.0154 \mathrm{x}$ & 0 \\
120 to 240 & $\mathrm{y}=0$ & 0 \\
\hline$>240$ & $\mathrm{y}=0$ & 0 \\
\hline
\end{tabular}

\subsection{Evaluations during Actual Storms}

From March through December, 2005, a total 24 pairs of inlet and outlet samples were collected during ten different storm events, from the 31 storms that occurred. The Tuscaloosa, Alabama, city hall test site was about 0.9 acres ( $0.36 \mathrm{ha})$ in area, comprising a steep aluminum roof, a concrete parking deck, and an asphalt parking deck, plus some small areas of older flat commercial roofs.

Sampling was conducted using two ISCO 6712 automatic samplers. The flow rates were determined using two ISCO 4250 area-velocity meters which also measured the stage both in the influent sump (the catchbasin sump) and in the effluent pipe. The rainfall intensity and amount were measured using a standard tipping bucket rain gauge. A small totalizing rain gauge was also used as a cross check. YSI 6600 water quality sondes were used to measure real time water quality data (temperature, dissolved oxygen, $\mathrm{pH}$, ORP (oxidation reduction potential), turbidity, conductivity, and water depth) of the influent and the effluent flows at 1 min. intervals during storm 
flows and at $5 \mathrm{~min}$. intervals during interevent periods. Once the appropriate samples were selected for analyses, the samples were divided using a Dekaport/USGS cone splitter (Rickly Hydrological Company). Every storm evaluated had a hyetograph (rainfall pattern) and hydrograph (runoff pattern) prepared with the treatment flow capacity marked for that particular event. An example is shown in Figure 9.7. A minimum sample volume of $400 \mathrm{~mL}$ was required to conduct the analyses. All the constituents were measured for both corresponding influent and effluent samples. The samples were evaluated for TS, SS, Escherichia coli, total coliforms, nitrates, total phosphorus, Chemical Oxygen Demand, heavy metals (focusing on copper, lead, and zinc), and particle size distributions.
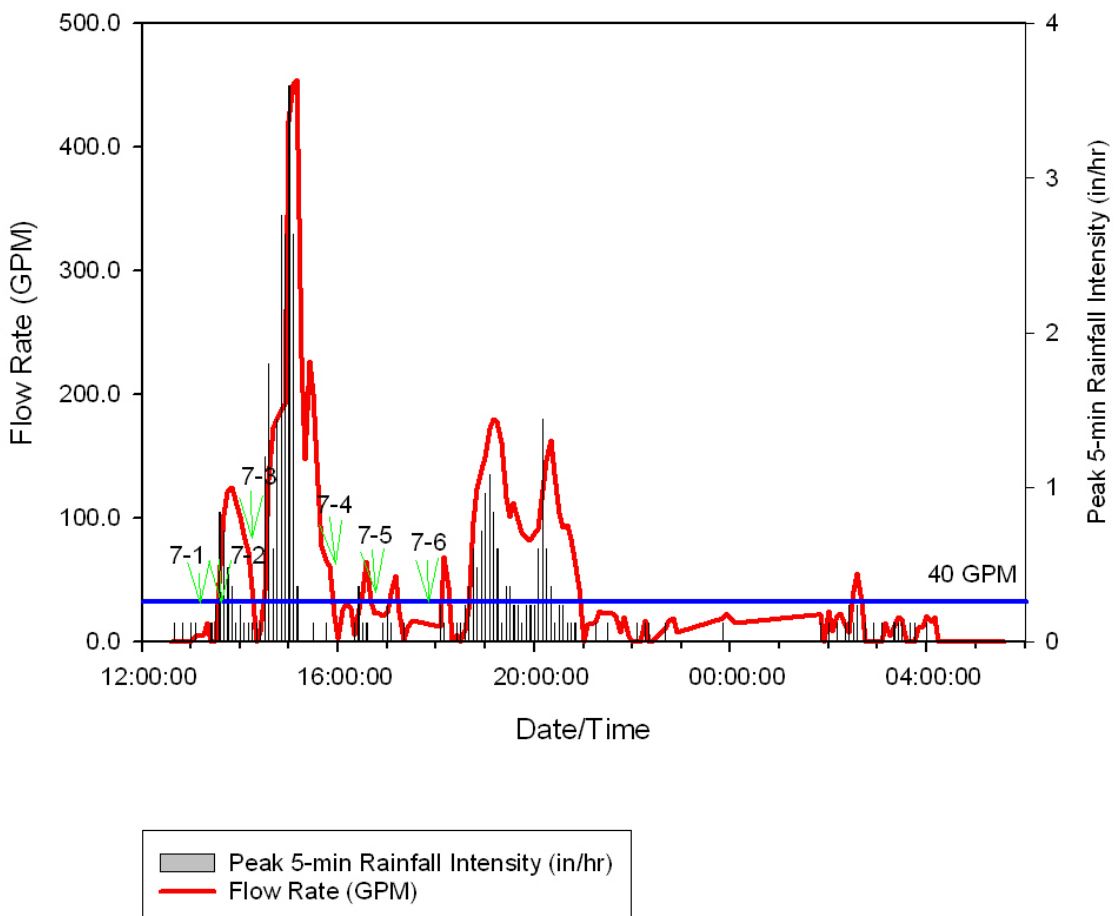

Figure 9.7 Hydrograph and hyetograph for hurricane Katrina, August 29, 2005. 
The 10-month monitoring period started off unusually dry in the late winter to early summer months. However, the mid summer was notable for severe thunderstorms having peak rain intensities (5-min) of up to $4 \mathrm{in} / \mathrm{h}$. The late summer was also notable for several hurricanes, including Hurricane Katrina on August 29, 2005 (Figure 9.7) that delivered about 3 in. of rain over a $15 \mathrm{~h}$ period, having peak rain intensities as high as $1 \mathrm{in} / \mathrm{h}$ in the Tuscaloosa area.

During the monitoring period, the treatment flow rates in the prototype $\mathrm{UpFlo}^{\mathrm{TM}}$ filter decreased with time, as expected. Figure 9.8 shows the decreasing flow rate with rain depth. The flow rate through the filter was always greater than the specified $25 \mathrm{gpm}(1.57 \mathrm{~L} / \mathrm{s})$ treatment flow rate during the 10 month period. It is estimated that the $25 \mathrm{gpm}$ treatment flow would be reached after about 30 in. $(770 \mathrm{~mm}$ ) of rainfall (in an area with 0.9 acre (0.37 ha) of impervious surfaces), or after about $45,000 \mathrm{ft}^{3}$ $\left(1271 \mathrm{~m}^{3}\right)$ of runoff, or $160 \mathrm{lbs}(73 \mathrm{~kg})$ of particulate solids, was treated by the filter.

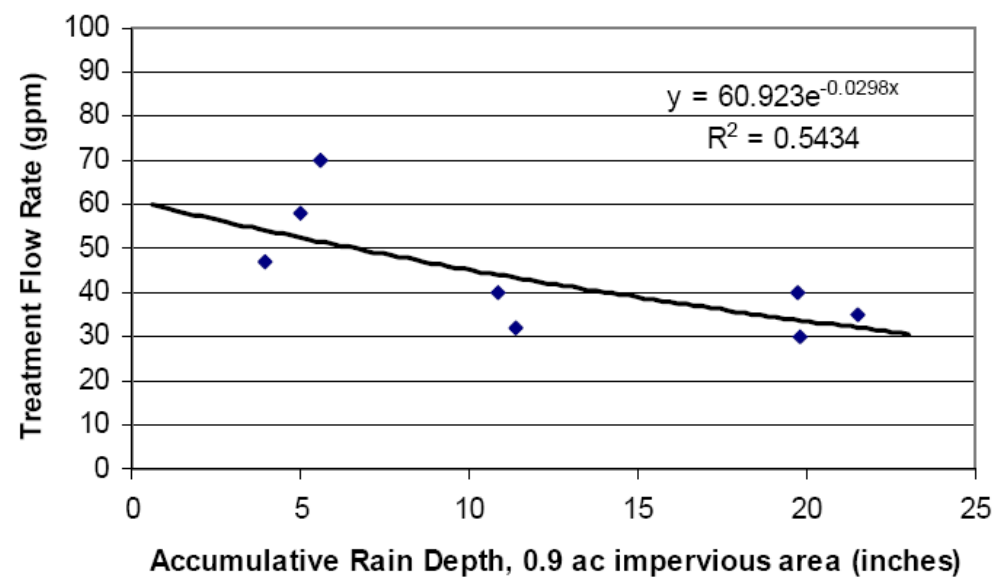

Figure 9.8 $\mathrm{UpFlo}^{\mathrm{TM}}$ filter treatment rate with rain depth.

Tables 9.2 and 9.3, and Figures 9.9 through 9.14 summarize the performance of the $\mathrm{UpFlo}^{\mathrm{TM}}$ filter during the monitored storms for suspended solids. Similar analyses were conducted for the other pollutants, and for each particle size range. This set of illustrations presents a comprehensive review of the performance of the filter. Simple statements concerning the percentage removal, for example, are inaccurate, as that 
indicator of performance is highly dependent on the influent concentrations and particle size distributions. In Table 9.2 the sample numbers are numbered by the storm event monitored and sample collected. For example, a sample number 2-1 indicates monitored storm $2,1^{\text {st }}$ collected sample.

Table 9.2 Observed suspended solids concentrations.

\begin{tabular}{rccccc}
\hline $\begin{array}{c}\text { Sample } \\
\text { Number }\end{array}$ & $\begin{array}{l}\text { Influent } \\
(\mathrm{mg} / \mathrm{L})\end{array}$ & $\begin{array}{l}\text { Effluent } \\
(\mathrm{mg} / \mathrm{L})\end{array}$ & $\begin{array}{l}\text { Sample } \\
\text { Number }\end{array}$ & $\begin{array}{c}\text { Influent } \\
(\mathrm{mg} / \mathrm{L})\end{array}$ & $\begin{array}{c}\text { Effluent } \\
(\mathrm{mg} / \mathrm{L})\end{array}$ \\
\hline $1-1$ & 17 & 4 & $6-4$ & 17 & 3 \\
$2-1$ & 53 & 36 & $6-5$ & 21 & 3 \\
$2-2$ & 50 & 37 & $7-1$ & 83 & 36 \\
$3-1$ & 6 & 0 & $7-2$ & 43 & 30 \\
$3-2$ & 3 & 1 & $7-3$ & 29 & 33 \\
$4-1$ & 1 & 0 & $7-4$ & 23 & 6 \\
$4-2$ & 1 & 0 & $7-5$ & 5 & 4 \\
$5-1$ & 80 & 37 & $7-6$ & 4 & 150 \\
$5-2$ & 15 & 17 & $8-1$ & 913 & 18 \\
$6-1$ & 5 & 6 & $8-2$ & 41 & 2 \\
$6-2$ & 11 & 8 & $9-1$ & 29 & 17 \\
\hline $6-3$ & 15 & 13 & $10-1$ & 72 & \\
\hline
\end{tabular}

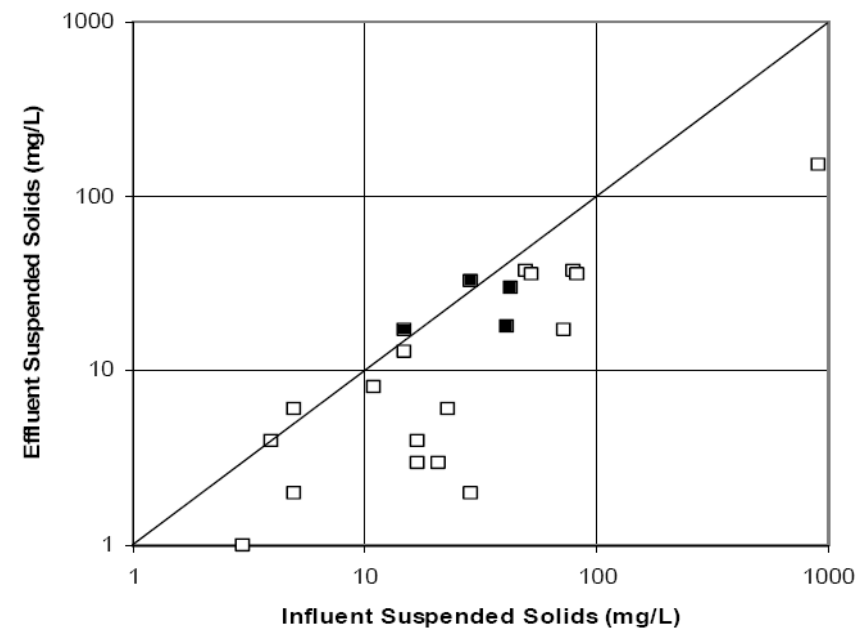

Figure 9.9 Scatterplot of observed influent and effluent suspended solids concentrations (filled in symbols indicated events that had minor bypasses around the filter). 


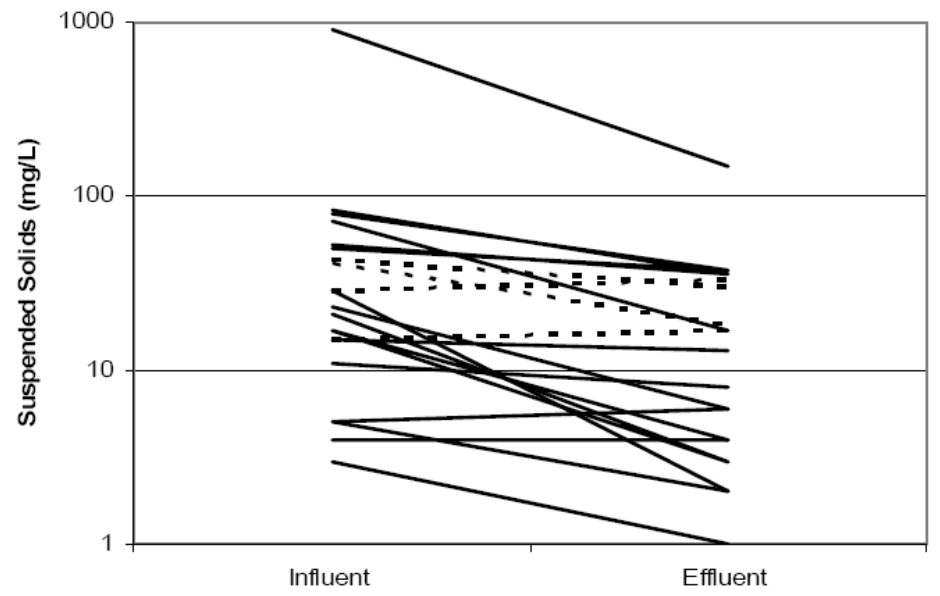

Figure 9.10 Paired influent and effluent suspended solids concentrations.

Fitted Equation:

Effluent Suspended Solids, $\log \mathrm{mg} / \mathrm{L}=0.730 *$ (Influent Suspended Solids, $\log \mathrm{mg} / \mathrm{L}$ )

Table 9.3 Regression statistics on observed influent vs. effluent suspended solids, log mg/L.

\begin{tabular}{lr}
\hline Multiple R & 0.94 \\
\hline R Square & 0.89 \\
Adjusted R Square & 0.85 \\
Standard Error & 0.37 \\
\hline Observations & 24 \\
\hline
\end{tabular}

\begin{tabular}{|c|c|c|c|c|c|c|}
\hline ANOVA & $\mathrm{df}$ & SS & MS & $\mathrm{F}$ & \multicolumn{2}{|c|}{ Significance F } \\
\hline Regression & 1 & 25.4 & 25.4 & 187 & \multicolumn{2}{|c|}{$3.11 \mathrm{E}-12$} \\
\hline Residual & 23 & 3.12 & 0.136 & & & \\
\hline Total & 24 & 28.55 & & & & \\
\hline & Coefficients & $\begin{array}{l}\text { Standard } \\
\text { Error }\end{array}$ & t Stat & P-value & $\begin{array}{c}\text { Lower } \\
95 \%\end{array}$ & $\begin{array}{c}\text { Upper } \\
95 \%\end{array}$ \\
\hline $\mathrm{X}$ Variable $1^{*}$ & 0.730 & 0.053 & 13.7 & $1.56 \mathrm{E}-12$ & 0.620 & 0.841 \\
\hline
\end{tabular}

* The intercept term was determined to be not significant 


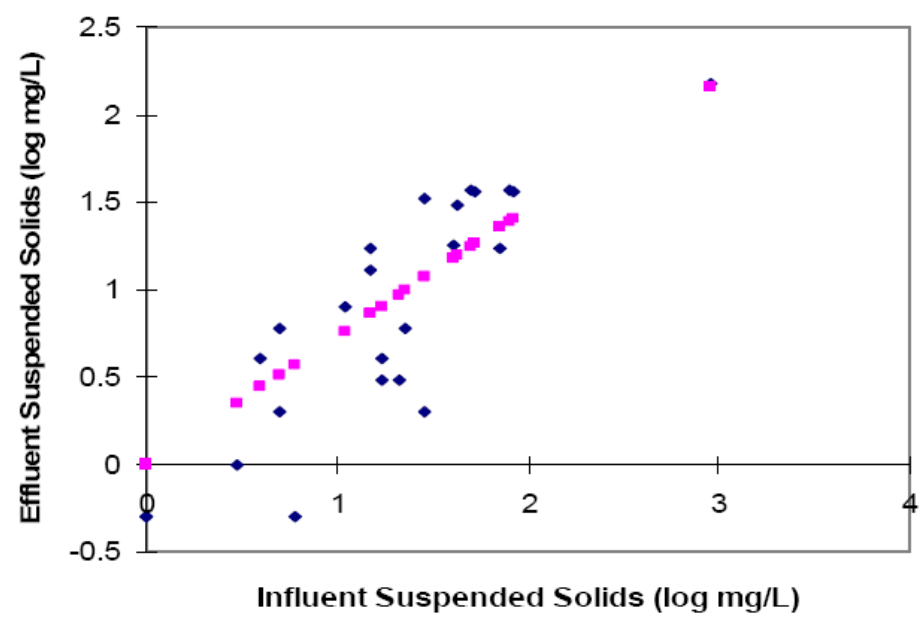

Figure 9.11 Fitted equation and data points for influent and effluent suspended solids.
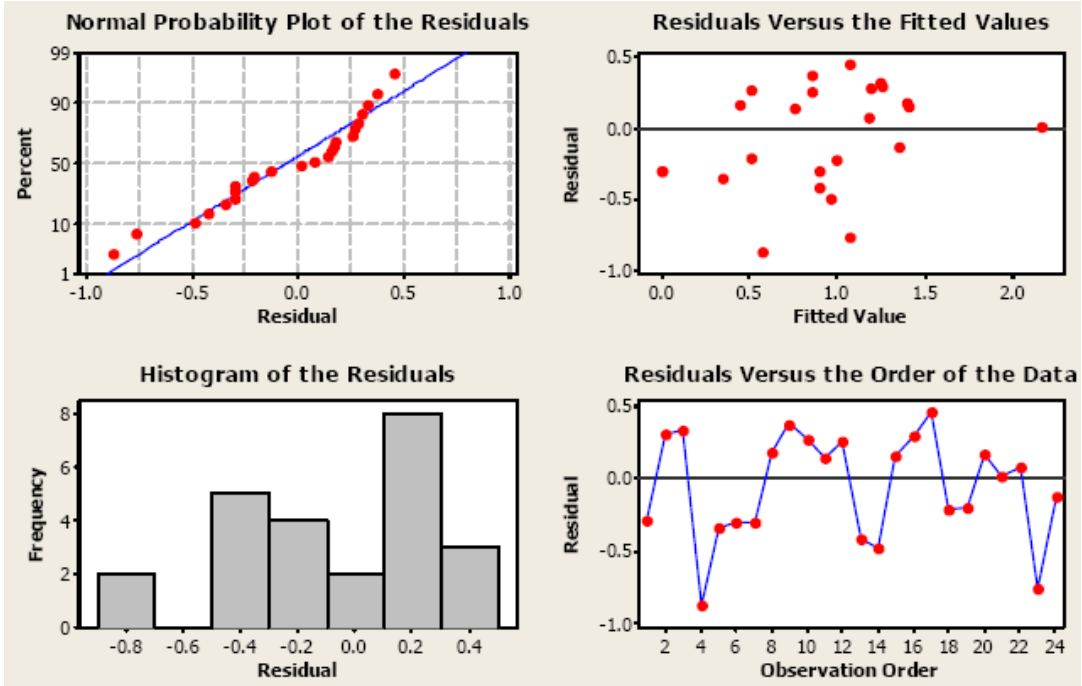

Figure 9.12 Residual analyses of fitted equation for suspended solids influent vs. effluent. 
As expected, the $\mathrm{UpFlo}^{\mathrm{TM}}$ filter performance followed traditional patterns, with greater percentage reductions as the influent concentrations increased (Figure 9.14). However, effluent quality is likely a more important consideration for many analyses, as shown in Figure 9.13. The effluent suspended solids was found to be less than $30 \mathrm{mg} / \mathrm{L}$ for all influent concentrations less than about $100 \mathrm{mg} / \mathrm{L}$, and the effluent was less than 100 $\mathrm{mg} / \mathrm{L}$ when the influent was less than about $600 \mathrm{mg} / \mathrm{L}$. The measured percentage reductions for suspended solids was found to be greater than $70 \%$, when influent concentrations were greater than $90 \mathrm{mg} / \mathrm{L}$.

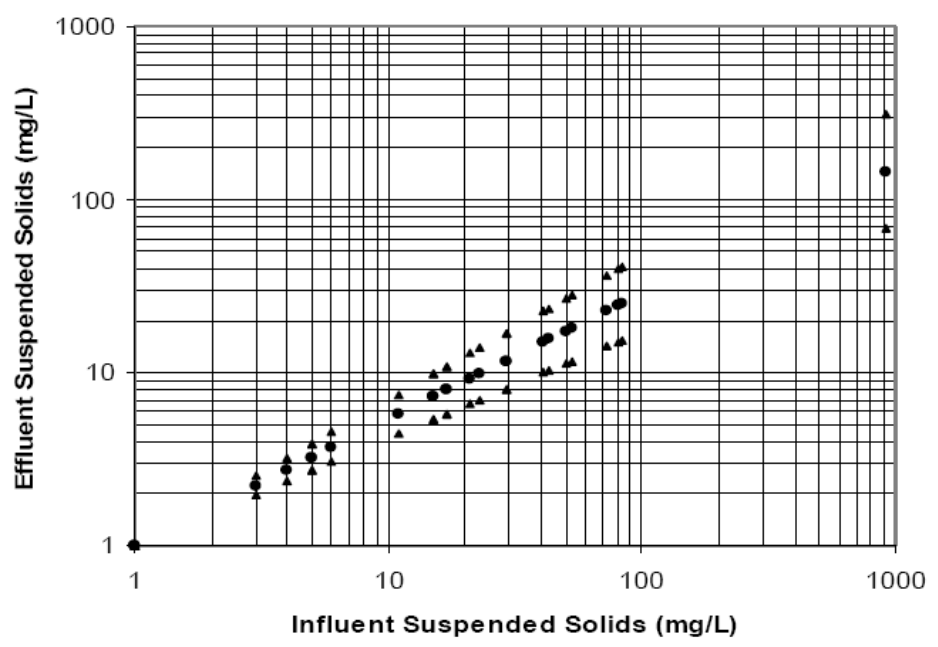

Figure 9.13 Predicted effluent suspended solids concentrations for different influent concentrations, with 95\% confidence limits.

The long-term performance of the $\mathrm{UpFlo}^{\mathrm{TM}}$ filter is highly dependent on the percentage of the annual runoff that is treated by the unit, like all treatment devices. A series of calculations were made, using WinSLAMM, the Source Loading and Management Model, to determine the distribution of flows that could be expected for several sets of conditions. Sizing plots for one acre paved parking or storage areas for five locations in the US having very different rainfall conditions were examined (Seattle, Phoenix, Atlanta, Milwaukee, and Portland, Maine). Figure 9.15 shows the annual runoff distributions for Portland, and Figure 9.16 the calculated percentage of the annual flows that would be treated at different treatment flow rates. 


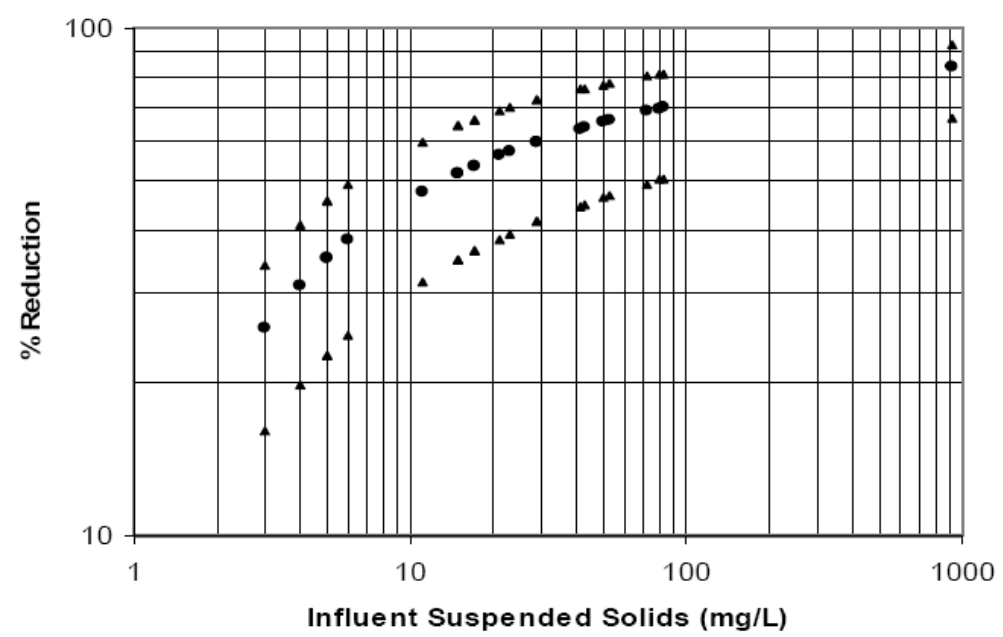

Figure 9.14 Percentage reductions of suspended solids as a function of influent concentrations, with $95 \%$ confidence limits.

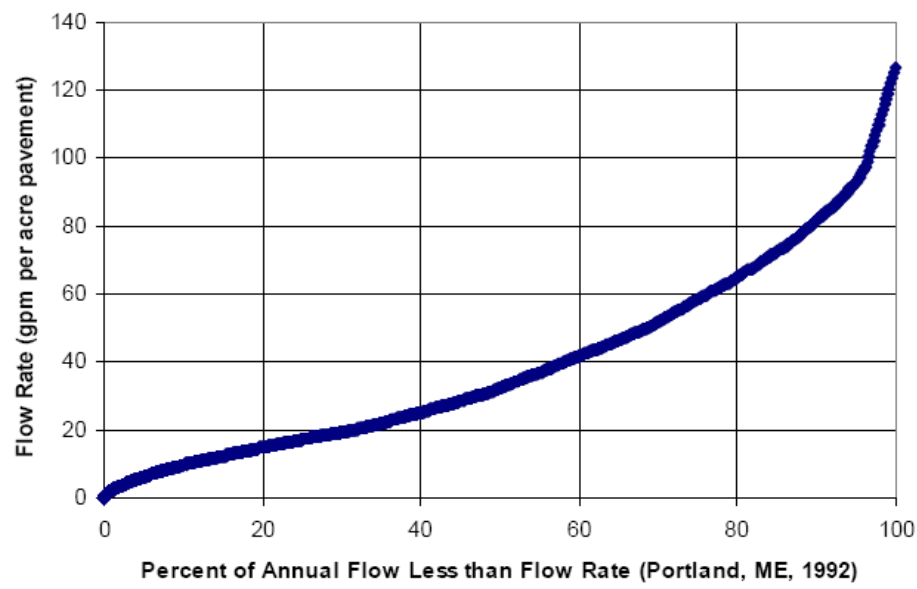

Figure 9.15 Treatment flow rates needed for Portland, Maine. 


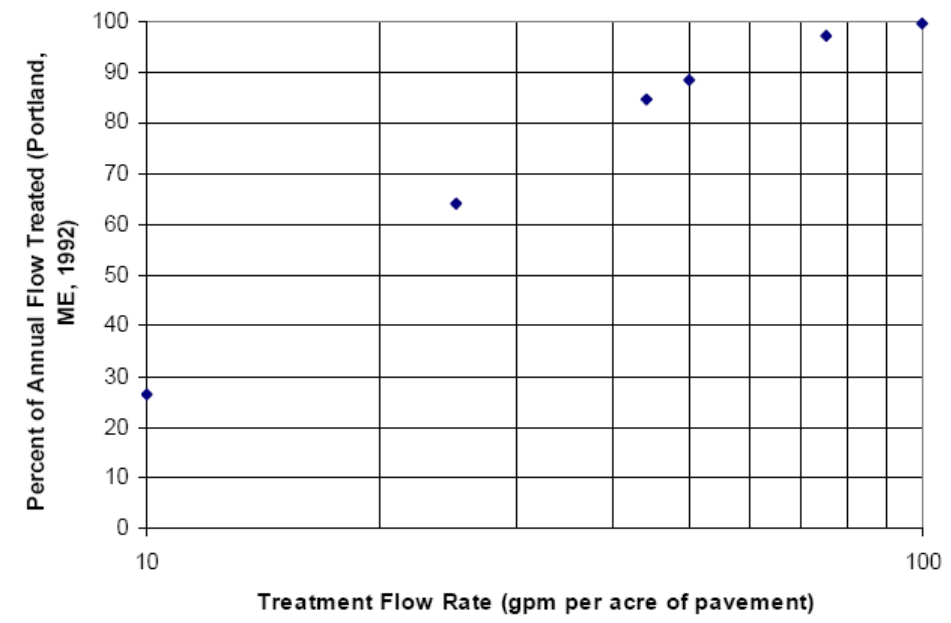

Figure 9.16 Treatment flow rates needed for Portland, Maine.

Table 9.4 Example flow rates and treatment rates needed for different treatment objectives.

\begin{tabular}{lllllll}
\hline & & $\begin{array}{c}\text { Annual Flow Rate Distributaries } \\
\text { (gpm/acre pavement) }\end{array}$ & \multicolumn{3}{c}{$\begin{array}{c}\text { Flow Rate Needed for } \\
\text { Different Levels of Annual } \\
\text { Flow Treatment } \\
\text { (gpm/acre pavement) }\end{array}$} \\
\hline Location & $50^{\text {th }}$ & $70^{\text {th }}$ & $90^{\text {th }}$ & $50 \%$ & $70 \%$ & $90 \%$ \\
& Percentile & Percentile & Percentile $^{2}$ & & & \\
\hline Seattle, WA & 16 & 28 & 44 & 10 & 18 & 30 \\
Portland, ME & 31 & 52 & 80 & 18 & 30 & 53 \\
Milwaukee, & 35 & 60 & 83 & 20 & 35 & 65 \\
WI & & 60 & 150 & 20 & 35 & 90 \\
Phoenix, AZ & 38 & 65 & 160 & 25 & 40 & 100 \\
Atlanta, GA & 45 & & & & & \\
\hline
\end{tabular}

Table 9.4 summarizes these calculations showing several treatment objectives. It is interesting to note that Seattle, typically known as a wet and rainy city, has the lowest flow rates for the probability points shown, and the smallest required treatment flow rates for the different treatment objectives. 
UpFlow Filtration for Treatment at Critical Source Areas

Table 9.5 Summary of UpFlo ${ }^{\mathrm{TM}}$ filter actual storm event monitoring (filter only, no sump effects).

\begin{tabular}{|c|c|c|c|c|}
\hline & $\begin{array}{l}\text { Average } \\
\text { influent } \\
\text { concentration** } \\
\left(\text { and } \mathrm{COV}^{*}\right)\end{array}$ & $\begin{array}{l}\text { Average } \\
\text { effluent } \\
\text { concentration** } \\
\text { (and COV) }\end{array}$ & $\begin{array}{l}\text { Percent } \\
\text { Removal*** }\end{array}$ & $\begin{array}{l}\text { Probability that influent } \\
\neq \text { effluent } * * * *\end{array}$ \\
\hline Turbidity (NTU) & $43(2.4)$ & $15(1.3)$ & $65(45)$ & $\begin{array}{l}>99 \% \text { (significant } \\
\text { reduction) }\end{array}$ \\
\hline Suspended solids & $64(2.9)$ & $19(1.6)$ & $70(58)$ & $\begin{array}{l}>99 \% \text { (significant } \\
\text { reduction) }\end{array}$ \\
\hline Total solids & $137(1.7)$ & $90(1.3)$ & $34(17)$ & $\begin{array}{l}>99 \% \text { (significant } \\
\text { reduction) }\end{array}$ \\
\hline COD & $111(1.6)$ & $81(1.4)$ & $27(18)$ & $\begin{array}{l}>99 \% \text { (significant } \\
\text { reduction) }\end{array}$ \\
\hline Phosphorus & $0.94(1.1)$ & $0.77(1.4)$ & $18(13)$ & $\begin{array}{l}98 \% \text { (significant } \\
\text { reduction) }\end{array}$ \\
\hline Nitrates & $0.7(1.2)$ & $0.7(1.3)$ & $0(0)$ & $\begin{array}{l}93 \% \text { (not significant } \\
\text { reduction) }\end{array}$ \\
\hline Ammonia & $0.44(1.5)$ & $0.24(1.30)$ & $45(24)$ & $\begin{array}{l}97 \% \text { (significant } \\
\text { reduction) }\end{array}$ \\
\hline E. coli & $4,750(0.8)$ & $3,290(0.8)$ & $31(21)$ & $\begin{array}{l}>99 \% \text { (significant } \\
\text { reduction) }\end{array}$ \\
\hline Total coliforms & $12,400(1.0)$ & $6,560(0.7)$ & $47(37)$ & $\begin{array}{l}>99 \% \text { (significant } \\
\text { reduction) }\end{array}$ \\
\hline $\begin{array}{l}\text { Total Zinc } \\
(\mu \mathrm{g} / \mathrm{L})\end{array}$ & $169(1.2)$ & $130(1.3)$ & $23(23)$ & $\begin{array}{l}>99 \% \text { (significant } \\
\text { reduction) }\end{array}$ \\
\hline $\begin{array}{l}\text { Total Copper } \\
(\mu \mathrm{g} / \mathrm{L})\end{array}$ & $13(1.5)$ & $8.7(1.2)$ & $33(26)$ & $\begin{array}{l}64.1 \% \text { (not significant } \\
\text { reduction) }\end{array}$ \\
\hline $\begin{array}{l}\text { Total Lead } \\
(\mu \mathrm{g} / \mathrm{L})\end{array}$ & $15.5(1.9)$ & $5.5(1.9)$ & $65(50)$ & $\begin{array}{l}90.8 \% \text { (significant } \\
\text { reduction) }\end{array}$ \\
\hline $\begin{array}{l}\text { Dissolved Lead } \\
(\mu \mathrm{g} / \mathrm{L})\end{array}$ & $11.3(2.7)$ & $2.8(2.2)$ & $75(58)$ & $\begin{array}{l}97.8 \% \text { (significant } \\
\text { reduction) }\end{array}$ \\
\hline$<0.45 \mu \mathrm{m}$ & $0.087(3.1)$ & $0.69(4.6)$ & $-690(60)$ & $\begin{array}{l}90.4 \% \text { (not significant } \\
\text { reduction) }\end{array}$ \\
\hline 0.45 to $3 \mu \mathrm{m}$ & $4.4(1.7)$ & $1.7(1.6)$ & $61(65)$ & $\begin{array}{l}98.9 \% \text { (significant } \\
\text { reduction) }\end{array}$ \\
\hline 3 to $12 \mu \mathrm{m}$ & $13.4(3.3)$ & $3.9(1.5)$ & $71(67)$ & $\begin{array}{l}90.7 \% \text { (not significant } \\
\text { reduction) }\end{array}$ \\
\hline 12 to $30 \mu \mathrm{m}$ & 28.7 (3.6) & $6.1(2.2)$ & $79(65)$ & $\begin{array}{l}>99 \% \text { (significant } \\
\text { reduction) }\end{array}$ \\
\hline 30 to $60 \mu \mathrm{m}$ & $12.0(2.1)$ & $4.5(1.9)$ & $63(72)$ & $\begin{array}{l}>99 \% \text { (significant } \\
\text { reduction) }\end{array}$ \\
\hline 60 to $120 \mu \mathrm{m}$ & $3.1(1.7)$ & $1.5(2.0)$ & $52(47)$ & $\begin{array}{l}97.4 \% \text { (significant } \\
\text { reduction) }\end{array}$ \\
\hline
\end{tabular}

*Co-efficient of Variation

** all $\mathrm{mg} / \mathrm{L}$, except for bacteria that are $\# / 100 \mathrm{~mL}$ and turbidity that is NTU

*** based on average concentrations, excluding additional removal by sump component

$* * * *$ nonparametric sign test, significant reduction at $95 \%$ level 
In this sampling of cities, the needed treatment flow rates for the same treatment objectives are seen to range by a factor of about three or four: it would require four $\mathrm{UpFlo}^{\mathrm{TM}}$ filter modules per acre of paved drainage area to treat about $90 \%$ of the annual runoff in Atlanta (similar to what was found for the Tuscaloosa test site during the monitoring period), while only one or two modules would be needed for the same area and treatment level objective for Seattle.

\subsection{Conclusions}

The $\mathrm{UpFlo}^{\mathrm{TM}}$ filter is most effective in reducing pollutants associated with particulate matter and less effective for dissolved constituents. Table 9.5 summarizes the overall performance of the $\mathrm{UpFlo}^{\mathrm{TM}}$ filter for the 24 pairs of samples evaluated, without considering the additional benefits of the sump.

Table 9.6 summarizes the expected mass balance of particulate material removed by the $\mathrm{UpFlo}^{\mathrm{TM}}$ filter during the sampling period, considering both the measurements from the automatic samplers (for suspended material $<150 \mu \mathrm{m}$ in size) and the larger material retained in the sump, assuming all the runoff was treated by the filter, with no bypass. The suspended solids removal rate is expected to be about $80 \%$, while the removal rates for the other monitored particulate constituents are expected to be about 72 to $84 \%$, depending on their associations with the different particle sizes, as shown on Table 9.7 and 9.8 for particulate phosphorus and particulate zinc.

Table 9.6 Calculated mass balance of particulate solids for monitoring period.

\begin{tabular}{lrrrr}
\hline $\begin{array}{l}\text { particle size } \\
\text { range }(\mu \mathrm{m})\end{array}$ & $\begin{array}{l}\text { SS influent mass } \\
(\mathrm{kg})\end{array}$ & $\begin{array}{l}\text { SS effluent mass } \\
(\mathrm{kg})\end{array}$ & $\begin{array}{l}\text { SS removed } \\
(\mathrm{kg})\end{array}$ & \% reduction \\
\hline $0.45-3$ & 9.3 & 2.8 & 6.6 & 70 \\
$3-12$ & 18.7 & 6.4 & 12.3 & 66 \\
$12-30$ & 22.4 & 7.7 & 14.7 & 66 \\
$30-60$ & 26.7 & 6.8 & 19.9 & 74 \\
$60-120$ & 4.6 & 1.8 & 2.9 & 61 \\
$120-250$ & 19.8 & 4.3 & 15.5 & 78 \\
$250-425$ & 11.5 & 0.0 & 11.5 & 100 \\
$425-850$ & 17.1 & 0.0 & 17.1 & 100 \\
$850-2,000$ & 10.5 & 0.0 & 10.5 & 100 \\
$2,000-4,750$ & 4.8 & 0.0 & 4.8 & 100 \\
$>4,750$ & 3.5 & 0.0 & 3.5 & 100 \\
\hline sum & 148.9 & 29.8 & 119.2 & 80 \\
\hline
\end{tabular}


Table 9.7 Calculated mass balance of particulate phosphorus for monitoring period.

\begin{tabular}{lrlrr}
\hline $\begin{array}{l}\text { particle size range } \\
(\mu \mathrm{m})\end{array}$ & $\begin{array}{l}\text { P influent mass } \\
\text { (grams) }\end{array}$ & $\begin{array}{l}\text { P effluent mass } \\
\text { (grams) }\end{array}$ & $\begin{array}{l}\text { P removed } \\
(\text { grams })\end{array}$ & \% reduction \\
\hline $0.45-3$ & 33.4 & 9.9 & 23.5 & 70 \\
$3-12$ & 66.9 & 22.9 & 44.0 & 66 \\
$12-30$ & 80.3 & 27.5 & 52.7 & 66 \\
$30-60$ & 95.6 & 24.5 & 71.1 & 74 \\
$60-120$ & 7.5 & 2.9 & 4.6 & 61 \\
$120-250$ & 10.1 & 2.2 & 7.9 & 78 \\
$250-425$ & 3.6 & 0.0 & 3.6 & 100 \\
$425-850$ & 8.5 & 0.0 & 8.5 & 100 \\
$850-2,000$ & 9.0 & 0.0 & 9.0 & 100 \\
$2,000-4,750$ & 6.7 & 0.0 & 6.7 & 100 \\
$>4,750$ & 6.0 & 0.0 & 6.0 & 100 \\
\hline sum & 328.0 & 90.4 & 237.6 & 72 \\
\hline
\end{tabular}

Table 9.8 Calculated mass balance of particulate zinc for monitoring period.

\begin{tabular}{lrrrr}
\hline $\begin{array}{l}\text { particle size range } \\
(\mu \mathrm{m})\end{array}$ & $\begin{array}{l}\text { Zn influent mass } \\
\text { (grams) }\end{array}$ & $\begin{array}{l}\text { Zn effluent mass } \\
\text { (grams) }\end{array}$ & $\begin{array}{l}\text { Zn removed } \\
\text { (grams) }\end{array}$ & \% reduction \\
\hline $0.45-3$ & 12.5 & 3.7 & 8.8 & 70 \\
$3-12$ & 25.0 & 8.6 & 16.5 & 66 \\
$12-30$ & 30.0 & 10.3 & 19.7 & 66 \\
$30-60$ & 35.8 & 9.2 & 26.6 & 74 \\
$60-120$ & 4.4 & 1.7 & 2.7 & 61 \\
$120-250$ & 9.9 & 2.1 & 7.8 & 78 \\
$250-425$ & 6.2 & 0.0 & 6.2 & 100 \\
$425-850$ & 4.6 & 0.0 & 4.6 & 100 \\
$850-2,000$ & 4.3 & 0.0 & 4.3 & 100 \\
$2,000-4,750$ & 2.2 & 0.0 & 2.2 & 100 \\
$>4,750$ & 2.0 & 0.0 & 2.0 & 100 \\
\hline sum & 137.2 & 35.8 & 101.4 & 74 \\
\hline
\end{tabular}

\section{Acknowledgments}

The SBIR1 (Small Business Innovative Research) and SBIR2 projects were sponsored by the US EPA, under the direction of Richard Field. The industrial partners included USInfrastructure (Ramjee Raghavan), Hydro International, Ltd., (many staff members), and StormTrain, LLC.'s Dave 
Woelkers. The City of Tuscaloosa (especially Chad Christian), and the Tuscaloosa Water Department assisted in the test site installation. Numerous University of Alabama graduate students and staff also assisted in many aspects of the project. The help and support of these project participants is gratefully acknowledged.

\section{References}

Khambhammettu, U. (2006). Evaluation of Upflow Filteration for the Treatment of Stormwater. MS, Environmental Engineering thesis, Department of Civil, Construction, and Environmental Engineering, The University of Alabama.

Pitt, R., R. Raghavan. S. Clark, M. Pratap, and U. Khambhammettu (2005). Upflow Filters for the Rapid and Effective Treatment of Stormwater at Critical Source Areas. Small Business Innovative Research (SBIR) Phase II, Annual Progress Report. US EPA, Edison, New Jersey.

Pitt, R., R. Raghavan. S. Clark, and U. Khambhammettu (2006). Field Verification Tests of the UpFlo ${ }^{T M}$ Filter. Small Business Innovative Research, Phase 2 (SBIR2) Report. U.S. Environmental Protection Agency, Edison, NJ. 275 pages. 